\title{
Efektywność ekonomiczna wybranych instytucji systemu finansowego samorządu terytorialnego
}

\section{Economic Efficiency of Selected Financial System Institutions of Local Government}

\begin{abstract}
Streszczenie. Funkcjonowanie jednostek samorządu terytorialnego w sferze ekonomicznej opiera się na regulacjach prawnych w obszarze prawa finansowego, które służą rozwiązywaniu określonych problemów gospodarczo-społecznych. Analiza efektywności ekonomicznej wprowadzanych regulacji ma szczególne znaczenie przy zmianie podejścia Unii Europejskiej do wpływu, jaki wywiera na gospodarkę działalność samorządu terytorialnego. Realizacja budżetów samorządowych opierających się na przepisach, których efektywność ekonomiczna nie została oszacowana na etapie legislacji, może mieć negatywny wpływ na funkcjonowanie społeczności lokalnych oraz na sytuację gospodarczą państwa. Częste zmiany przepisów prawa finansowego powodują podejmowanie działań, których skutków finansowych nie można przewidzieć. Ponadto niestabilne przepisy uniemożliwiają prawidłowe zaplanowanie podstawowych pozycji budżetowych, co ma duże znaczenie w aspekcie poprawności wieloletnich prognoz finansowych jednostek samorządu terytorialnego.
\end{abstract}


Słowa kluczowe: budżet; jednostka samorządu terytorialnego; efektywność ekonomiczna; analiza ekonomiczna prawa; poziom zadłużenia; metoda wskaźnikowa; program postępowania naprawczego; zobowiązania dłużne; indywidualny wskaźnik zadłużenia.

\begin{abstract}
Functioning of local government units, as for as the economic sphere is concerned, is based on the financial law regulations. Those regulations aim at solving economic and social problems. The analysis of economic efficiency concerning implemented regulations is of particular importance for changing the EU's attitude towards the influence, which EU has on functioning of the local governments. Implementing the local budgets, based on regulations which economic efficiency hasn't been evaluated on the stage of legislation, may have a negative impact on local community and the economic situation of the country. Frequent changes of financial law cause actions, which financial effects cannot be predicted. What is more, those unstable regulations make it impossible to plan essential parts of a budget in a right way. That has a great importance in terms of correctness of long-term financial perspectives of the local government units.
\end{abstract}

Keywords: budget; the local government; economic efficiency; economic analysis of law; the level of debt indicator method; recovery program; debt obligations; individual debt ratio.

\title{
1. Wprowadzenie
}

Założenie efektywności ekonomicznej instytucji systemu finansowego samorządu terytorialnego powinno być ważnym elementem konstruowania norm prawnych. Stosowanie przepisów prawa, których skutki finansowe nie zostały przeanalizowane wielowariantowo, bez ujęcia pełnego zakresu działania jednostek samorządu terytorialnego i ich otoczenia zewnętrznego, może doprowadzić do problemów w ich funkcjonowaniu. Szczególnie w dobie kryzysu gospodarczego przewidywanie skutków ekonomicznych projektowanych norm prawnych, których stosowanie może mieć wpływ na lokalne społeczności, wydaje się mieć pierwszorzędne znaczenie na etapie tworzenia prawa. Przyjęte założenia, bez analizy ich efektywności, powodują powstanie schematów teoretycznych, które często w różnorodnych i zmiennych warunkach rzeczywistości nie przynoszą zamierzonych efektów. 
Celem opracowania jest omówienie nowych rozwiązań wprowadzonych w ustawie o finansach publicznych z 2009 r. ${ }^{1}$ dotyczących instytucji prawnofinansowych służących organizacji zasobów pieniężnych i planowania wieloletniego $^{2}$, ze szczególnym uwzględnieniem:

1. wymogu zrównoważenia budżetu w jego części bieżącej na etapie planowania oraz wykonania,

2. dopuszczalnego wskaźnika spłat zobowiązań dłużnych wraz z należnościami ubocznymi,

3. programu postępowania naprawczego.

Zmiany podstaw prawnych uchwalania i realizacji budżetów jednostek samorządu terytorialnego wprowadzane zostały do systemu finansowego samorządów od 2010 r., czyli od wejścia w życie ustawy o finansach publicznych z 2009 r. (i w jej kolejnych nowelizacjach). Sposób organizacji zasobów pieniężnych jednostek samorządu terytorialnego został ukierunkowany na przywrócenie stanu równowagi finansów publicznych oraz na osiągnięcie średniookresowego celu budżetowego (MTO) ${ }^{3}$. Ograniczenia ustawowe obejmujące

1 Ustawa z dnia 27 sierpnia 2009 r. o finansach publicznych (tekst jedn. Dz.U. z 2013 r., poz. 885 ze zm.), dalej: u.f.p.

2 W. Miemiec, K. Sawicka, M. Miemiec, Prawo finansów publicznych sektora samorzqdowego, Warszawa 2013, s. 52-53.

3 Cele MTO to saldo strukturalne sektora instytucji rządowych i samorządowych, które powinno zostać osiągnięte przez państwo będące członkiem Unii Europejskiej w średnim okresie. Saldo strukturalne budżetu nie zostało zdefiniowane w przepisach ustawy o finansach publicznych. W nauce o finansach publicznych przyjęło się, iż saldo strukturalne stanowi saldo rzeczywiste skorygowane o zmiany cykliczne oraz o działania jednorazowe i tymczasowe. Stąd też oprócz określenia „saldo strukturalne” stosuje się również określenie „saldo skorygowane o wahania cykliczne”. Saldo strukturalne (saldo skorygowane o wahania cykliczne) jest wielkością hipotetyczną, informującą o tym, jaka byłaby wielkość salda budżetu przy braku wpływu czynników cyklicznych (gdyby rzeczywista produkcja równała się produkcji potencjalnej). Saldo strukturalne stanowi bardzo istotną miarę oceny polityki fiskalnej w Unii Europejskiej. Na mocy postanowień zawartych w Pakcie na rzecz Stabilności i Wzrostu dla państw członkowskich, których walutą jest euro, oraz dla państw członkowskich uczestniczących w ERM2 krajowe średniookresowe cele budżetowe ustalane są w ramach określonego przedziału pomiędzy $-1 \%$ PKB a równowagą lub nadwyżką, w ujęciu uwzględniającym zmiany cykliczne, po skorygowaniu o działania jednorazowe i tymczasowe. Informacje o średniookresowym celu budżetowym zawierają zarówno programy stabilności, przekazywane przez państwa członkowskie, których walutą jest euro, jak i programy konwergencji, sporządzane przez państwa inne niż te, których walutą jest euro. Zgodnie z przepisami rozporządzenia Rady Nr 1466/97/WE z dnia 7 lipca 1997 r. 
proces konstruowania budżetu i jego rzeczywistej realizacji zawarte w art. art. 240, 242 i 243 u.f.p. częściowo zapisane w postaci matematycznej umożliwiają przeprowadzenie analizy w kontekście ekonomicznej analizy prawa.

\section{Sprawiedliwość i efektywność ekonomiczna prawa}

Sprawiedliwość jest to pojęcie rozumiane jako właściwość czyjegoś postępowania, która polega na tym, że wszystkie osoby należące do tej samej kategorii są traktowane i oceniane w jednakowy sposób. W ujęciu aksjologicznym uznaje się też, że sprawiedliwość jest jedną z głównych, obok równości i wolności, wartości społecznych. Konstytucja Rzeczpospolitej Polskiej już w art. 2 wskazuje, że Polska jest państwem urzeczywistniającym zasady sprawiedliwości społecznej ${ }^{4}$. W komentarzach do Konstytucji pojęcie sprawiedliwości jest definiowane jako nakaz tworzenia sprawiedliwego prawa i uchylania prawa niesprawiedliwego ${ }^{5}$.

Działanie efektywne to takie, które jest skuteczne i przynosi właściwe rezultaty ${ }^{6}$. Efektywność ekonomiczna prawa powinna polegać na za-

w sprawie wzmocnienia nadzoru pozycji budżetowych oraz nadzoru i koordynacji polityk gospodarczych (Dz.Urz. UE L 209 z 02.08.1997 r., str. 1) po zmianach wprowadzonych rozporządzeniem Parlamentu Europejskiego i Rady (UE) nr 1175/2011 z dnia 16 listopada 2011 r. (Dz.Urz. UE L 306 z 23.11.2011 r., str. 12) w obu przypadkach ocena tego, czy postęp na drodze do osiągnięcia średniookresowego celu budżetowego jest wystarczający, jest przeprowadzana na podstawie oceny ogólnej, w której punktem odniesienia jest saldo strukturalne. Na tej samej podstawie oceniane jest odstępstwo od średniookresowego celu budżetowego lub odpowiedniej ścieżki dostosowawczej prowadzącej do niego. Od momentu przystąpienia do Unii Europejskiej Polska jest zobowiązana do podporządkowania się obowiązującym w niej regułom odnośnie kontrolowania poziomu deficytu. Stąd w programach konwergencji, opracowywanych zgodnie z wytycznymi dotyczącymi programów stabilności i konwergencji państw członkowskich Unii Europejskiej, rząd przedstawia prognozy w zakresie wyniku strukturalnego. Źródło: Public finances in EMU - 2000, „European Economy” 2000, nr 3, s. 14 i 157; Report on Public finances in EMU 2012, „European Economy”2012, nr 4, s. 316, DOI: http://dx.doi.org/10.2765/18911

4 Konstytucja Rzeczpospolitej Polskiej z dnia 2 kwietnia 1997 r. (Dz.U. Nr 78, poz. 483 ze zm.).

5 J. Boratyński, Sprawiedliwość społeczna w Konstytucji, „Edukacja Prawnicza” 2009, nr 5, s. 12.

$6 \quad$ S. Dubisz (red.), Uniwersalny słownik języka polskiego PWN, t.1, Warszawa 2003. 
pewnieniu tworzenia regulacji efektywnych, a co za tym idzie skutecznych i funkcjonalnych ${ }^{7}$. Analiza ekonomiczna prawa w ujęciu pozytywnym stara się wyjaśnić rzeczywiste funkcjonowanie przepisów prawa i jego skutki, a w ujęciu normatywnym bada, czy dane rozwiązanie przyjęte przez system prawa może prowadzić do niepożądanych społecznie skutków. Aby taką analizę przeprowadzić, konieczne jest stworzenie odpowiedniego modelu, inaczej mówiąc, uproszczonego obrazu rzeczywistości. W najnowszej literaturze $\mathrm{z}$ dziedziny ekonomii rozpoczęła się, w związku z trwającym kryzysem gospodarczym, krytyka takiego sposobu myślenia. Wyrażanie wszystkiego za pomocą modeli i liczb stało się niebezpiecznym dogmatem, ponieważ jak się okazało, zbytnie zawierzenie liczbom nie potrafi uchronić przed popełnieniem błędu. Wyrazicielem takiego stanowiska jest europejski ekonomista Tomasz Sedlaczek, który twierdzi, że „ekonomia [...] domaga się wyłączności na rozumienie świata[...]” oraz że „na podstawie liczb może przewidzieć przyszłość”8. Takie krytyczne podejście do analizy ekonomicznej wynika również z ostatnich zdarzeń w gospodarkach krajów Unii Europejskiej. Nadmienić należy, że działania, które wywołały kryzys gospodarczy, były oparte na bardzo liberalnych przepisach i były zgodne z prawem. Tworzenie modelu, który jest oderwany od systemu, i ocenianie jedynie efektywności w bardzo wąskim zakresie, może powodować błędną ocenę stanu faktycznego i zaciemnić prawdziwy obraz rzeczywistości. Nie oznacza to jednak, że nie należy dążyć do efektywności ekonomicznej prawa.

Zgodnie z założeniami najsłynniejszej koncepcji ekonomicznej analizy prawa, zaproponowanej przez Richarda Posnera, prawo jest co do zasady ekonomicznie efektywne. Ekonomicznie efektywne rozwiązanie problemu to takie, które maksymalizuje funkcję użyteczności społecznej ${ }^{9}$. W analizie ekonomicznej prawa trzeba wyceniać wartości, którym trudno jednoznacznie przypisać wartość ekonomiczną. Przypisanie wartości ma

7 R.T. Stroiński, Ekonomiczna analiza prawa czyli w oszukiwaniu efektywności, „Kwartalnik Prawa Prywatnego", 2002, nr 3, s. 552.

8 T. Sedlaczek, Ekonomia to niebezpieczna religia, „Dziennik Gazeta Prawna” 2012, nr 233 (z dn. 30 listopada 2012 r.).

$9 \quad$ J. Stelmach, B. Brożek, Metody prawnicze, Kraków 2006, s. 137. 
często charakter bardzo subiektywny. Zbudowany model matematyczny może nie zawierać wszystkich istotnych dla sprawy uwarunkowań. W rezultacie ocena efektywności ekonomicznej przyjętych rozwiązań prawnych może się okazać błędna.

Krytyczne podeście do ekonomicznej analizy prawa nie wynika $\mathrm{z}$ faktu negowania dotychczasowego dorobku naukowego, ale ma na celu wykazanie, że w dynamicznej sytuacji rozwoju określone działania wywołają różne skutki. Trudność polega więc na przewidywaniu przy zastosowaniu nowoczesnych technologii i sporządzaniu bardzo wnikliwych analiz prawnych opartych na rzeczywistych danych. Prawo musi iść za postępującymi zmianami społeczno-ekonomicznymi, a następnie powinno przyszłe zmiany (najważniejsze tendencje społeczne i ekonomiczne) prognozować. Jest to możliwe, jeśli wyjdziemy poza pozytywistyczny paradygmat myślenia o prawie, o jego (absolutnym) obowiązywaniu i trwaniu w czasie. Nowo tworzone prawo musi być „otwarte" na przyszłość, musi uwzględniać dynamikę dokonujących się zmian społecznych, politycznych oraz ekonomicznych. W przeciwnym razie stanie się ono albo przedmiotem nieustannych nowelizacji, albo po prostu prawem martwym ${ }^{10}$.

W doktrynie rzadko się mówi o wpływie polityki na stanowienie prawa. A to właśnie polityka ma często wpływ na jego kształt i skutki społeczne, jakie prawo powoduje. W zależności od tego, czy wprowadzona regulacja prawna jest w stanie doprowadzić do zamierzonych przez nią skutków, powinno się określać, czy ingerencja ustawowa nie jest nadmierna w kontekście konstytucyjnych celów i wartości (zasada proporcjonalności) ${ }^{11}$. Realizacja konstytucyjnych norm (art. 2 Konstytucji) w przypadku nadmiernej ingerencji państwa jest trudna. Każda regulacja wynikająca z zapotrzebowania politycznego jest zbyt powierzchowna, przeprowadzona zbyt szybko i bez odpowiednich konsultacji. Część uregulowań uznanych na etapie tworzenia prawa może się wydawać sprawiedliwa społecznie i nawet efektywna ekonomicznie.

10 J. Stelmach, B. Brożek, W. Załuski, Dziesięć wykładów o ekonomii prawa, Warszawa 2007, s. 20-22, 181-194.

11 J.M. Salachna, Granice samodzielności legislacyjnej jednostek samorzq̨u terytorialnego, Gdańsk 2012, s. 66. 


\section{Dopuszczalny wskaźnik spłat zobowiązań dłużnych wraz z należnościami ubocznymi}

Ustawa o finansach publicznych z 2005 r. ${ }^{12}$ zawierała sztywno ustalone limity zadłużenia jednostek samorządu terytorialnego i jego spłat, określone w art. 169 i art. 170 ${ }^{13}$. Ustanowione w ten sposób limity były poddawane krytyce, która wskazywała wyraźnie, że nie odnoszą się one do rzeczywistej sytuacji danej jednostki samorządu terytorialnego ${ }^{14}$. W przygotowanej w 2006 r. przez Ministerstwo Finansów nowelizacji prawa finansów publicznych założono, że dopuszczalny limit spłat zaciągniętych kredytów będzie zależał od relacji nadwyżki operacyjnej ${ }^{15}$ do dochodów z ostatnich trzech lat i nie będzie mógł przekroczyć 90\% tej relacji. Jednak ostatecznie nowelizacja u.f.p. w 2005 roku w powyższym kształcie nie została dokonana.

Ustawa o finansach publicznych z 2009 r. wprowadziła nowe kryteria oceny, których poziom wykonania warunkuje możliwość zadłużenia oraz możliwość uchwalenia budżetu przez jednostki samorządu terytorialnego, począwszy od 2014 r. Przepisy artykułu 243 u.f.p. wprowadziły zasadę obliczania odpowiednich wskaźników według wzoru matematycznego,

12 Ustawa z dnia 30 czerwca 2005 r. o finansach publicznych (Dz.U. Nr 249, poz. 1240 ze zm.), dalej: u.f.p. z 2005 r.

13 Art. 169 u.f.p. określał relację łącznej kwoty przypadających w danym roku budżetowym spłat rat kredytów i pożyczek wraz z należnymi odsetkami, wykupów papierów wartościowych emitowanych przez jednostki samorządu terytorialnego wraz z należnymi odsetkami i dyskontem oraz potencjalnych spłat kwot wynikających z udzielonych przez jednostki samorządu terytorialnego poręczeń i gwarancji do planowanych na dany rok budżetowy dochodów jednostki samorządu terytorialnego, która nie mogła przekroczyć $15 \%$, natomiast art. 170 u.f.p. określał relację łącznej kwoty długu jednostki samorządu terytorialnego na koniec roku budżetowego do wykonanych dochodów ogółem tej jednostki w tym roku budżetowym. Relacja ta nie mogła przekroczyć $60 \%$.

14 T. Swianiewicz, Finanse lokalne - teoria i praktyka, Warszawa 2004, s. 131.

15 Nadwyżka operacyjna to różnica dochodów bieżących i wydatków bieżących. Pojęcie wydatków bieżących jest zdefiniowane w polskim prawie i ich wyodrębnienie w oparciu o obowiązującą klasyfikację budżetową nie nastręcza większych trudności. Dochody bieżące są to te dochody, które mają charakter stały, powtarzalny, związany z regularną działalnością jednostki samorządowej. Są więc nimi np.: podatki lokalne, opłaty za usługi, a także subwencja ogólna i inne dochody na zaspokajanie potrzeb bieżących jednostek samorządowych. 
klasyfikującego jednakowo wszystkie samorządy terytorialne, bez względu na ich rzeczywistą sytuację. Wydaje się to sprawiedliwe. Jednak czystość tych regulacji burzą szczególne wyłączenia i przywileje dla niektórych jednostek. Takie wyłączenia zawiera nie tylko ustawa o finansach publicznych, ale również inne akty prawne.

Obowiązująca ustawa o finansach publicznych, w związku z art. 121 ust. 2 ustawy Przepisy wprowadzające ustawę o finansach publicznych ${ }^{16}$, wprowadziła od 2014 r. regulację zobowiązującą samorząd terytorialny do uwzględnienia po raz pierwszy w uchwałach budżetowych na 2014 r. indywidualnego wskaźnika zadłużenia jednostki samorządu terytorialnego obliczonego na podstawie danych z lat 2011-2013. Aby przygotować organy stanowiące jednostek samorządu terytorialnego do podjęcia uchwał budżetowych na 2014 rok, wieloletnie prognozy finansowe w latach 2011-2013 zawierały dane do wyliczenia indywidualnego wskaźnika oraz wskazywały w sposób wyraźny jego tendencje w kolejnych latach objętych prognozą. Samorządy miały zatem trzy lata na podjęcie działań zmierzających do dostosowania swoich budżetów do nowych wymogów ustawowych.

Regulacje dotyczące dopuszczalnego wskaźnika spłat zobowiązań dłużnych wraz z należnościami ubocznymi i określonego przez zdolność jednostki samorządu terytorialnego do spłaty zadłużenia, zawarte są $\mathrm{w}$ art. 242 i 243 u.f.p. Rozgraniczenie budżetu na część bieżącą (administracyjną, operacyjną) i majątkową (inwestycyjną, kapitałową) było podstawą do wprowadzenia regulacji dotyczącej konieczności zrównoważenia budżetu w części operacyjnej (art. 242 u.f.p.). Ustawodawca złagodził jednak powyższy wymóg poprzez możliwość pokrywania deficytu bieżącego nadwyżką budżetową z lat poprzednich lub wolnymi środkami z kredytu ${ }^{17}$.

16 Ustawa z dnia 27 sierpnia 2009 r. Przepisy wprowadzające ustawę o finansach publicznych (Dz.U. Nr 157, poz. 1241 ze zm.).

17 Wolne środki z kredytu należy rozumieć jako środki pieniężne, które nie zostały zaangażowane na finansowanie wydatków lub rozchodów w poprzednim okresie. Pochodzą one z zaciągniętych, ale niewykorzystanych w całości kredytów i pożyczek oraz wpływów z wyemitowanych papierów wartościowych. Wolnymi środkami są również uzyskane w poprzednich latach spłaty pożyczek udzielonych przez jednostkę samorządu terytorialnego. 
Dodatkowo przyjęto, że możliwa jest sytuacja, w której wydatki bieżące są wyższe od dochodów bieżących powiększonych o nadwyżki z lat ubiegłych i wolne środki z kredytu, o ile różnica stanowi kwotę wydatków bieżących realizowanych z udziałem środków pomocowych. Jest to przypadek, kiedy dana jednostka samorządu terytorialnego nie uzyskała zaplanowanej refundacji (nie wykonała planowanych dochodów). Wiąże się to z systemem rozliczania z instytucjami zarządzającymi, które ze względów proceduralnych nie zawsze są $\mathrm{w}$ stanie zrealizować płatności $\mathrm{w}$ danym roku budżetowym. Sytuacja taka została przewidziana przez ustawodawcę w art. 242 ust 3 u.f.p. Zrównoważenie budżetu w części bieżącej dotyczy wartości zarówno planowanych, jak i wykonanych. Oznacza to, że jednostka samorządu terytorialnego nie może zaciągać długu na wydatki bieżące, na które brakuje pokrycia w dochodach bieżących. Finansowanie wydatków bieżących przy udziale nadwyżki budżetowej i wolnych środków z kredytu jest dla jednostek samorządu terytorialnego niekorzystne ze względu na dyspozycję art. 243 u.f.p. Ponieważ źródłem finansowania deficytu budżetowego może być nadwyżka budżetowa z lat poprzednich i wolne środki z kredytu, to ich przeznaczenie na finansowanie wydatków bieżących wiąże się ze wzrostem zapotrzebowania jednostki samorządu terytorialnego na zasilane zwrotne (zaciąganie zobowiązań dłużnych).

W ustawie z dnia 7 grudnia 2012 r. o zmianie niektórych ustaw w związku z realizacją ustawy budżetowej ${ }^{18}$ na mocy art. 36 ust. 1 ustawodawca przewidział czasowe wyłączenia (na lata 2013-2015) z wydatków bieżących uwzględniane przy wyliczaniu nadwyżki operacyjnej. Powyższe wyłączenia dotyczą tych jednostek samorządu terytorialnego, które:

1. poniosły wydatki bieżące na spłaty zobowiązań samodzielnego publicznego zakładu opieki zdrowotnej, przekształconego na zasadach określonych w ustawie z dnia 15 kwietnia 2011 r. o działalności leczniczej ${ }^{19}$,

18 Dz.U., poz. 1456 ze zm.

19 Tekst jedn. Dz.U. z 2013 r. poz. 217 ze zm. 
2. dokonały rozchodów z tytułu spłat kredytów i pożyczek zaciągniętych na powyższy cel w wysokości, w jakiej nie podlegają one finansowaniu dotacją z budżetu państwa.

W doktrynie często podkreśla się, że gdyby nie zastosowano powyższego wyłączenia, jednostki samorządu terytorialnego nie mogłyby ze względów finansowoprawnych przejmować zobowiązań zakładów opieki zdrowotnej. Wydaje się jednak, że powyższe stanowisko zostało zawężone do tych samorządów, które przez wiele lat zadłużania się służby zdrowia, handlu długami zakładów opieki zdrowotnej oraz pogarszającej się jakości świadczonych usług zdrowotnych nie podejmowały aż do $2011 \mathrm{r}$. działań mających na celu zmianę tej sytuacji.

Wyłączenia stawiają w uprzywilejowanej pozycji te podmioty, które przeprowadziły restrukturyzację służby zdrowia na mocy ustawy o działalności leczniczej. Całkowicie natomiast pomijają te samorządy, które dużym wysiłkiem finansowym, często rozłożonym na wiele lat, dokonały restrukturyzacji zadłużenia szpitali wcześniej, w poprzednio obowiązującym stanie prawnym. Ważne z punktu widzenia ekonomicznej analizy prawa wydaje się w tym miejscu zwrócenie uwagi na fakt, że wprowadzone wyłączenia powodują zachwianie zasady maksymalizacji dobrobytu społecznego wszystkich społeczności. Efektywne ekonomicznie działania jednostek samorządu terytorialnego, podejmowane zgodnie z prawem i w interesie społeczności lokalnych, okazały się w dłuższej perspektywie czasu przyczyną trudności samorządów w wypracowaniu nadwyżki operacyjnej ${ }^{20}$.

Pomimo faktu posiadania przez Ministerstwo Finansów narzędzi do przeprowadzania analiz skutków ekonomicznych nowych regulacji prawnych $^{21} \mathrm{w}$ uzasadnieniach do projektów ustaw lub ich zmian brakuje in-

20 Wydatki ponoszone przez jednostkę samorządu terytorialnego na spłatę odsetek od zaciągniętych kredytów na restrukturyzację służby zdrowia stanowią wydatek bieżący. Szczególnie samorządy powiatowe, których dochody własne w tym dochody bieżące są ograniczone (brak danin publicznych), a które nie mogą skorzystać z opisanych wyłączeń, mają problem w zrównoważeniu budżetu w części bieżącej.

21 W 2006 r. Ministerstwo Finansów wdrożyło w jednostkach samorządu terytorialnego System BESTI@, który powstał w ramach projektu Transition Facility 2006/018180.01.04 „System zarządzania budżetami jednostek samorządu terytorialnego - spra- 
formacji dotyczących wyników takich analiz oraz skutków finansowych dla budżetu państwa. Efekt jest taki, że skutki finansowe, które ponoszą jednostki samorządu terytorialnego, a w efekcie budżet państwa, są niewspółmierne do kosztów przeprowadzenia dogłębnych analiz.

Ustalenie kwoty nadwyżki operacyjnej jest punktem wyjścia do dokonania obliczeń z zastosowaniem wzoru matematycznego stanowiącego podstawę oceny zdolności spłaty zobowiązań przez daną jednostkę samorządu terytorialnego - art. 243 u.f.p.

Do wyliczania prognozy wskaźnika rocznych spłat względem planowanych dochodów budżetowych ujmuje się następujące zobowiązania:

1. planowane w danym roku spłaty rat kapitałowych kredytów i pożyczek zaciągniętych na sfinansowanie planowanego deficytu budżetu,

2. mające nastąpić w danym roku budżetowym spłaty rat kapitałowych kredytów i pożyczek zaciągniętych na spłatę wcześniej zaciągniętych zobowiązań z tytułu wyemitowanych papierów wartościowych oraz zaciągniętych kredytów i pożyczek,

3. spłaty zobowiązań dłużnych zaciągniętych na wyprzedzające finansowanie przedsięwzięć finansowanych ze środków budżetu Unii Europejskiej,

4. spłaty odsetek od zobowiązań z tytułu zaciągniętych kredytów i pożyczek, planowanych do spłaty odsetek od nowo zaciąganych kredytów i pożyczek, w tym na pokrycie przejściowego deficytu budżetowego,

5. wykup papierów wartościowych wraz z należnymi odsetkami,

6. potencjalne spłaty rat kapitałowych wraz z odsetkami od udzielonych lub planowanych ${ }^{22}$ poręczeń i gwarancji.

Wyliczenie indywidualnego wskaźnika zadłużenia i nadwyżki operacyjnej odbywa się na etapie opracowywania wieloletniej prognozy finan-

wozdawczość jednostek organizacyjnych”. Dane systemu BESTI@ są agregowane na poziomie województw przez regionalne izby obrachunkowe, a następnie przekazywane do Ministerstwa Finansów.

22 W wieloletniej prognozie finansowej jednostki samorządu terytorialnego ujmuje się potencjalne zobowiązania wynikające z udzielonych poręczeń i gwarancji oraz tych, które w roku budżetowym lub w kolejnych latach objętych prognozą zostaną udzielone i wynikają z upoważnień dla organu wykonawczego. 
sowej jednostki samorządu terytorialnego, przy uwzględnieniu zgodności danych z budżetem w danym roku budżetowym. Narzędziem służącym do przygotowania wieloletniej prognozy finansowej jest wspomniany system BESTI@, który jednakowo oblicza i prezentuje dane wszystkich jednostek samorządu terytorialnego. Dane potrzebne do wyliczenia indywidualnego wskaźnika zadłużenia w odniesieniu do rat kapitałowych oraz wykupu papierów wartościowych wynikają z zawartych umów. W przypadku zobowiązań z tytułu odsetek od kredytów i pożyczek jednostki samorządu terytorialnego przyjmują w objaśnieniach do wieloletniej prognozy finansowej założenia makroekonomiczne zbieżne z założeniami przyjętymi przez Radę Ministrów na etapie przygotowywania projektu budżetu państwa. Większość zaciąganych przez samorządy kredytów i pożyczek oprocentowanych jest według zmiennych stóp procentowych, gdzie bazą jest WIBOR $^{23}$ i marża banku. Trudność polega na zaplanowaniu spłaty zobowiązań odsetkowych w zmieniających się uwarunkowaniach gospodarczych i finansowych. Jednak największą trudnością, jaką napotykają samorządy, jest wyliczenie zobowiązania odsetkowego od kredytu zaciąganego na pokrycie przejściowego deficytu budżetowego. Ponieważ najczęściej jest to kredyt w rachunku bieżącym, który spłaca się po wpływie środków na rachunek bankowy, to wyliczenie rzeczywistego zobowiązania może być nieprecyzyjne. A więc mogą to być dane niepewne, których wysokość w zależności od wielkości limitu kredytowego może mieć znaczący lub mały wpływ na wyliczenie prognozowanego wskaźnika.

Podobnie jak w przypadku art. 242, również art. 243 u.f.p zawiera wyłączenia, które dotyczą spłaty określonych zobowiązań. Należą do nich następujące wyłączenia o charakterze stałym:

1. wykup papierów wartościowych, spłaty kredytów i pożyczek zaciągniętych w związku z umową zawartą na realizację programu, projektu oraz zadania, w związku z umową zawartą z podmiotami dys-

23 WIBOR (z ang. Warsaw Interbank Offered Rate) jest to wysokość oprocentowania pożyczek na polskim rynku bankowym. Wartość ustalana jest w każdy dzień roboczy o godz. 11.00 przez Polskie Stowarzyszenie Dealerów Bankowych - ACI. WIBOR wyliczany jest na podstawie średniej ofert złożonych przez 13 banków, po odrzuceniu dwóch najwyższych oraz dwóch najniższych wielkości. 
ponującymi środkami z budżetu Unii Europejskiej lub pomocy finansowej udzielanej przez państwa EFTA, o których mowa w art. 5 ust. 1 pkt 2 u.f.p.; Ustawa $\mathrm{z}$ dnia 8 listopada 2013 r. o zmianie ustawy o finansach publicznych oraz niektórych innych ustaw ${ }^{24}$ wprowadziła zmianę dotyczącą zaliczenia do powyższego wyłączenia odsetek i dyskonta. W celu umożliwienia samorządom korzystania w nowym okresie programowania 2014-2020 ze środków unijnych zmieniono poprzedni przepis, w wyniku czego jednostki samorządu terytorialnego mogą ująć do wyłączenia odsetki oraz dyskonto od powyższych zobowiązań ${ }^{25}$;

2. poręczenia i gwarancje udzielone i planowane do udzielenia samorządowym osobom prawnym realizującym zadania jednostki samorządu terytorialnego $\mathrm{w}$ ramach programów finansowanych $\mathrm{z}$ udziałem środków z budżetu Unii Europejskiej lub środków pomocy finansowej państw EFTA, o których mowa w art. 5 ust. 1 pkt 2 u.f.p.

Powyższe wyłączenia stosuje się w terminie nie dłuższym niż 90 dni po zakończeniu programu, projektu lub zadania i otrzymania refundacji z tych środków. Termin ten nie ma jednak zastosowania do odsetek i dyskonta od zobowiązań zaciągniętych na wkład krajowy z tytułu kredytów, pożyczek i wykupu papierów wartościowych ze względu na zastosowanie dodatkowego wyłączenia obejmującego te właśnie pozycje.

Jednostki samorządu terytorialnego realizujące projekty, programy lub zadania finansowane ze środków z budżetu Unii Europejskiej lub środków pomocy finansowej państw EFTA, o których mowa w art. 5 ust. 1 pkt 2 u.f.p., najpierw ponoszą 100\% wydatków, a dopiero po weryfikacji przez instytucje zarządzające otrzymują refundację poniesionych wydatków. W związku z tym kredyt zaciągnięty przez jednostkę samorządu terytorialnego na całość zadania może zostać spłacony w części po otrzy-

\footnotetext{
Dz.U., poz. 1646.

25 Ustawa z dnia 8 listopada 2013 r. o zmianie ustawy o finansach publicznych oraz niektórych innych ustaw wprowadziła zmianę art. 243 ust. 3 u.f.p. poprzez zmianę brzmienia pkt 1 oraz poprzez dodanie pkt 1a, co pozwoliło na podział zobowiązań na zobowiązania z tytułu kredytów i pożyczek oraz na wykup papierów wartościowych. Pozwoliło to dostosować przepisy dotyczące włączenia należnych z tych tytułów odsetek i dyskonta.
} 
maniu refundacji. Ustawodawca daje samorządom 90 dni od zakończenia programu na zastosowanie wyłączenia. Samorządy, które zadłużyły się wcześniej i które mają zaplanowane, zgodnie z umowami kredytowymi, spłaty rat kapitałowych na dany rok budżetowy, nie mają możliwości zwiększenia poziomu spłat z otrzymanej refundacji. Nie skorzystają one zatem z możliwości dokonania wyłączeń, o których mowa w art. 243 ust. 3 pkt 1 i 1a u.f.p.

Nowelizacja u.f.p. z 8 listopada 2013 r. wprowadziła dodatkowe wyłączenie dotyczące wykupu papierów wartościowych, spłat rat kredytów i pożyczek wraz z należnymi odsetkami i dyskontem, odpowiednio emitowanych lub zaciągniętych w związku z umową zawartą na realizacje programu, projektu lub zadania finansowanego w co najmniej 60\% ze środków z budżetu Unii Europejskiej lub środków pomocy finansowej państw EFTA, o których mowa w art. 5 ust. 1 pkt 2 u.f.p., w części odpowiadającej wydatkom na wkład krajowy finansowanych tymi zobowiązaniami. Wyłączenie to ma zastosowanie do wydatków wynikających z umowy o dofinansowanie zawartej po dniu 1 stycznia 2013 r. i poniesionych po tym dniu.

Zobowiązania wraz z odsetkami i dyskontem zaciągnięte na pokrycie wkładu krajowego przy zastrzeżeniu, że projekt, program i zadnie będzie finansowane w co najmniej 60\% ze środków z budżetu Unii Europejskiej lub środków pomocy finansowej państw EFTA, nie podlegają zgodnie z art. 243 ust.3 i ust 3a u.f.p. ograniczeniom czasowym - dotyczą całego okresu spłat.

Nowa regulacja daje ponadto samorządom możliwość realizacji projektów generujących dochód. Określono, że poziom finansowania ze środków z budżetu Unii Europejskiej lub środków pomocy finansowej państw EFTA ustala się po odliczeniu zdyskontowanego dochodu obliczonego zgodnie z przepisami Unii Europejskiej dotyczącymi takiego projektu programu lub zadania, a kwotę wydatków na wkład krajowy ustala się w wysokości jaka wynikałaby, gdyby poziom finansowania ze środków unijnych obliczony został bez uwzględnienia zdyskontowanego dochodu. 
Kolejny bardzo ważny wymóg u.f.p. nakłada na samorządy, które nie spełniają warunków, o których mowa w art. 243 ust. 3 i ust. 3a, lub gdy określone w umowie o dofinansowanie środki nie zostały przekazane lub został orzeczony ich zwrot. Jednostki samorządu terytorialnego niespełniające powyższych warunków nie mogą emitować papierów wartościowych, zaciągać kredytów i pożyczek ani udzielać poręczeń i gwarancji do czasu spełnienia relacji wskaźnika z art. 243 u.f.p. W relacji tej jednostka samorządu terytorialnego zobowiązana jest uwzględnić kwotę zobowiązań związaną z nieprzekazanymi środkami lub środkami, w stosunku do których orzeczono zwrot. Na podstawie analizy art. 243 ust. 4 nasuwa się pytanie: czy jednostka samorządu terytorialnego, która nie spełnia wymogów indywidualnego wskaźnika zadłużenia z podanych przyczyn, musi uchwalić program postępowania naprawczego ${ }^{26}$

Odpowiadając na powyższe pytanie, należy wrócić do teorii ekonomicznej analizy prawa, która zakłada, że nieefektywne regulacje są często nowelizowane, a tym samym założony przez ustawodawcę cel staje się nieczytelny. Tak jest również w tym przypadku. Art. 243 ust. 4 u.f.p. po nowelizacji zobowiązuje jednostki samorządu terytorialnego, w stosunku do których został orzeczony zwrot środków lub które nie otrzymały środków określonych w umowie o dofinansowanie ze środków z budżetu Unii Europejskiej lub środków pomocy finansowej państw EFTA, do uwzględnienia w wyliczeniu indywidualnego wskaźnika zadłużenia kwot zobowiązań z powyższych tytułów. Przepis ten zmienia zatem zakres danych niezbędnych do wyliczenia indywidualnego wskaźnika zadłużenia, wprowadzając konieczność uchwalenia programu postępowania naprawczego. Obecnie w sądach administracyjnych toczą się postępowania dotyczące tzw. korekt finansowych, które w wyniku przeprowadzonych kontroli instytucji zarządzających zostały naliczone samorządom. Te jednostki samorządu terytorialnego, które dokonały płatności wynikających z nałożonych korekt i dokonały zwrotów środków, nie muszą ich uwzględnić w wyliczeniu wskaźnika. Natomiast te samorządy, które we-

26 Art. 240a u.f.p. wprowadzony po jej nowelizacji 8 listopada 2013 r. przewiduje konieczność uchwalenia programu naprawczego w przypadku braku możliwości uchwalenia wieloletniej prognozy lub budżetu. 
szły na drogę postępowania sądowego z instytucjami zarządzającymi, są zobowiązane do ujęcia wynikających z tego faktu potencjalnych zobowiązań w obliczeniach już i tak trudnego do osiągnięcia indywidualnego wskaźnika zadłużenia. Ponadto ustawodawca nie określił precyzyjnie, czy chodzi o nieprzekazane środki lub środki w stosunku do których orzeczono zwrot w roku budżetowym, na który wyliczany jest wskaźnik, czy dotyczy też prawomocnych decyzji z lat poprzednich? Brak jest orzecznictwa w powyższym zakresie.

Wyłączenia, o których mowa, dotyczą zatem tylko tych jednostek, które realizowały projekty inwestycyjne przy współudziale środków z Unii Europejskiej. A więc nie dotyczą wszystkich samorządów w Polsce.

Dyskutować można również nad sposobem wyliczania wskaźników. Po przeprowadzeniu analizy zastosowanych w ustawie rozwiązań można stwierdzić jednoznacznie, że wartości wskaźników są warunkowane przez wiele zmiennych w czasie danych. Prowadzi to do sytuacji, w której obliczone wskaźniki zależą od sposobu prezentacji danych, a nie od prawdziwej sytuacji ekonomicznej jednostki samorządu terytorialnego. Ponadto konstrukcja wskaźnika art. 243 ust. 1 u.f.p - jak okazało się w praktyce nie zapewnia możliwości jego spełnienia takim jednostkom samorządu terytorialnego, które są niezadłużone i nie występują u nich nadwyżka operacyjna i dochody ze sprzedaży mienia:

dochody bieżq̨ce + dochody ze sprzedaży mienia - wydatki bieżq̨ce $=0$

W takim układzie prawa część wzoru przyjmuje wartość 0. Indywidualny wskaźnik zadłużenia, aby spełnić wymóg ustawowy, musiałby wynosić 0 lub być wartością ujemną, co jest w tym przypadku niemożliwe. Taki problem mają jednostki samorządu terytorialnego, które chcą zaciągnąć kredyt na finansowanie przejściowego deficytu i które znajdują się w sytuacji opisanej powyżej. Do wskaźnika dolicza się bowiem planowane do zapłaty odsetki z tytułu kredytu. Relacja odsetek od potencjalnego kredytu na finansowanie przejściowego deficytu do dochodów budżetu będzie stanowiła zawsze wartość większą od zera, a więc niemożliwe będzie zachowanie relacji z art. 243 ust. u.f.p. W związku z tym rów- 
nież samorządy niezadłużone, nieposiadające nadwyżki operacyjnej oraz dochodów ze sprzedaży mienia będą miały trudności w zaciągnięciu kredytu na pokrycie przejściowego deficytu budżetowego.

Drugą grupę stanowią wyłączenia o charakterze czasowym dotyczące lat 2014-2018. Na mocy art. 36 ust 2 ustawy z dnia 7 grudnia 2012 r. o zmianie niektórych ustaw w związki z realizacją ustawy budżetowej, w latach 2014-2018 ograniczeń w zakresie spłaty zobowiązań nie stosuje się do wykupu papierów wartościowych, spłat kredytów i pożyczek z wyłączeniem odsetek od tych zobowiązań, zaciąganych przez jednostkę samorządu terytorialnego na spłatę przejętych zobowiązań od samodzielnego publicznego zakładu opieki zdrowotnej przekształconego na zasadach określonych w ustawie z dnia 15 kwietnia 2011 r. o działalności leczniczej. W uzasadnieniu do rządowego projektu ustawy o zmianie niektórych ustaw ${ }^{27}$ stwierdzono, że wyłączenie kwot spłat rat kapitałowych zobowiązań dłużnych w wysokości związanej z pokryciem zobowiązań przekształcanych zakładów opieki zdrowotnej ze wskaźnika określonego wzorem matematycznym w art. 243 ust. 1 u.f.p. pomoże spełnić wymogi ustawowe tym samorządom, które przekształciły samodzielne publiczne zakłady opieki zdrowotnej. I analogicznie jak przy zastosowaniu wyłączeń z art. 242 u.f.p. taka regulacja w uprzywilejowanej sytuacji stawia wyłącznie określoną grupę samorządów. Wyłączenie to spełnia jednak funkcję korygującą inne regulacje, które wskazują, że pokrycie przez jednostkę samorządu terytorialnego ujemnego wyniku finansowego samodzielnego zakładu opieki zdrowotnej jest wydatkiem bieżącym, którego wysokość ma wpływ na wyliczenie nadwyżki operacyjnej i indywidualnego wskaźnika zadłużenia.

27 Uzasadnienie do rządowego projektu ustawy o zmianie niektórych ustaw w związku z realizacją ustawy budżetowej, druk sejmowy nr 809 z dnia 18 października 2012 r., http://orka.sejm.gov.pl/Druki7ka.nsf/0/9C90929F01175DF4C1257A9B004FF532/\%24 File/809.pdf (dostęp: 20 marca 2014 r.). 


\section{Program postępowania naprawczego}

Na wniosek strony samorządowej do u.f.p. nowelizacją z 8 listopada 2013 r. wprowadzono art. 240a, który daje jednostkom samorządu terytorialnego możliwość uchwalenia programu postępowania naprawczego. Podstawą do uchwalenia programu jest brak możliwości uchwalenia wieloletniej prognozy finansowej lub budżetu jednostki samorządu terytorialnego zgodnie z zasadami określonymi w art. 242- 243 u.f.p. oraz zagrożenia realizacji zadań publicznych przez jednostkę samorządu terytorialnego. Po przedłożeniu regionalnej izbie obrachunkowej projektu budżetu niespełniającego wymogów z art. 242-244 u.f.p. regionalna izba obrachunkowa wzywa jednostkę samorządu terytorialnego do opracowania i uchwalenia programu postępowania naprawczego oraz przedłożenia tego programu do zaopiniowania regionalnej izbie obrachunkowej w terminie 45 dni od dnia otrzymania wezwania. Zachowanie terminu 45 dni oraz terminu ustawowego na wydanie opinii przez regionalną izbę obrachunkową zgodnie z art.11 punkt 2a ustawy o regionalnych izbach obrachunkowych $^{28}$ uniemożliwia uchwalenie budżetu jednostki samorządu terytorialnego w ustawowym terminie do 31 stycznia $^{29}$.

Program postępowania naprawczego zawiera w szczególności: analizę stanu finansów jednostki samorządu terytorialnego z określeniem przyczyn zagrożenia realizacji zdań publicznych, plan przedsięwzięć naprawczych wraz $\mathrm{z}$ harmonogramem ich wprowadzenia $\mathrm{z}$ uwzględnieniem przewidywanych efektów finansowych i określeniem sposobu ich obliczania. Postępowanie naprawcze wiąże się dla jednostki samorządu terytorialnego z następującymi ograniczeniami:

28 Ustawa z dnia 7 października 1992 r. o regionalnych izbach obrachunkowych (tekst jedn. Dz.U. z 2012 r. poz. 1113 ze zm.).

29 Jednostki samorządu terytorialnego przedkładają do zaopiniowania regionalnej izbie obrachunkowej projekt wieloletniej prognozy finansowej oraz uchwały budżetowej na kolejny rok budżetowy do 15 listopada. Regionalna izba obrachunkowa ma 30 dni na wydanie opinii i wezwanie jednostki do opracowania programu naprawczego w terminie 45 dni od otrzymania wezwania. Ponadto regionalna izba obrachunkowa musi zaopiniować projekt programu naprawczego, a organ stanowiący uchwalić zgodnie $\mathrm{z}$ terminami określonymi w statucie danej jednostki samorządu terytorialnego. Niemożliwe jest zatem uchwalenie budżetu w terminie ustawowym, tzn. do 31 stycznia. 
1. brakiem możliwości podejmowania nowych inwestycji finansowanych kredytem, pożyczką lub emisją papierów wartościowych,

2. brakiem możliwości udzielania pomocy finansowej innym jednostkom samorządu terytorialnego,

3. brakiem możliwości udzielania poręczeń, gwarancji i pożyczek,

4. brakiem możliwości tworzenia funduszu sołeckiego,

5. możliwością realizacji tylko zadań obligatoryjnych finansowanych ze środków własnych,

6. począwszy od miesiąca następującego po miesiącu, w którym został przyjęty program postępowania naprawczego, wysokość wydatków na diety radnych i na wynagrodzenia zarządu jednostki samorządu terytorialnego nie może przekroczyć wysokości wydatków z tego tytułu z roku poprzedzającego rok, w którym została podjęta uchwała w sprawie programu postępowania naprawczego.

W przypadku, gdy jednostka samorządu terytorialnego nie opracuje programu postępowania naprawczego lub gdy regionalna izba obrachunkowa nie zaopiniuje pozytywne tego programu, budżet jednostki samorządu terytorialnego ustala regionalna izba obrachunkowa. Budżet może być ustalony bez zachowania relacji z art. 242-244 u.f.p w terminie do końca lutego roku budżetowego.

Trudności uchwalenia budżetów w wyniku przyjęcia programu postępowania naprawczego w terminach określonych w ostatniej nowelizacji u.f.p. przez jednostki samorządu terytorialnego i ustalenia budżetu przez regionalną izbę obrachunkową są podnoszone przez regionalne izby obrachunkowe. Konieczna zatem wydaje się nowelizacja art. 240a ust. 1 w zakresie terminów lub powrót do terminów z poprzednich ustaw o finansach publicznych, które precyzowały ostateczny termin uchwalenia budżetu przez jednostki samorządu terytorialnego na dzień 31 marca roku budżetowego, a ustalenia zastępczego budżetu przez regionalną izbę obrachunkową na dzień 30 kwietnia.

Wprowadzenie do ustawy o finansach publicznych nowej instytucji prawnofinansowej, jaką jest program postępowania naprawczego, spowodowało, że samorządy, które znalazły się w najtrudniejszej sytuacji finansowej zostały potraktowane tak samo, jak te, które nie posiadają nadwyżki 
operacyjnej oraz dochodów ze sprzedaży mienia. Istnieje również grupa samorządów, które pomimo zachowania płynności finansowej i możliwości pełnej realizacji zadań publicznych mają zbyt wysokie, według przyjętych zasad obliczania wskaźnika, obciążenie spłatami rat kapitałowych. Trudno jest $\mathrm{w}$ takiej sytuacji przygotować program postępowania naprawczego, który będzie polegał zasadniczo na wydłużeniu terminu spłat rat kapitałowych zobowiązań dłużnych, tzw. rozterminowaniu spłaty zobowiązań. W krótkim czasie przyniesie to skutek w postaci niższych rat kapitałowych i spełnienie wskaźnika z art. 243 u.f.p. W dłuższej perspektywie czasowej zwiększy koszty obsługi zobowiązań dłużnych oraz może uniemożliwić samorządom wykonywanie zadań inwestycyjnych ze względu na brak możliwości zadłużania w przyszłości ${ }^{30}$.

\section{Podsumowanie}

Analiza wybranych instytucji prawnofinansowych budzi poważne zastrzeżenia dotyczące w szczególności skutków ekonomicznych, nieprzewidzianych przez ustawodawcę, dla gospodarki finansowej jednostek samorządu terytorialnego oraz budżetu państwa.

Przede wszystkim zastosowanie metody wskaźnikowej dotyczącej konieczności obliczania indywidualnego wskaźnika zadłużenia, nieuwzględniającej sytuacji finansowej niemałej grupy jednostek samorządu terytorialnego, oznacza zróżnicowane i nie zawsze sprawiedliwe traktowanie tych jednostek. Zastanawiający jest również fakt, że wprowadzane regulacje nie są poddawane szczegółowym analizom tak prawnym, jak ekonomicznym. Stworzony w 2006 r. system BESTI@ umożliwia już choćby na poziomie jednostki samorządu terytorialnego wykonywanie analiz służących przewidywaniu przyszłych skutków prawnych i ekonomicznych dla budżetu jednostki. Zastosowanie metod analizy ekonomicznej prawa jest możliwe, jeżeli weźmie się pod uwagę posiadanie odpo-

30 Powyższe wnioski sformułowano na podstawie analizy wieloletnich prognoz finansowych jednostek samorządu terytorialnego województwa dolnośląskiego http://www.wroclaw.rio.gov.pl 
wiednich narzędzi i kadr. Brak takich analiz wydaje się wynikać bardziej z tempa, w jakim są uchwalane zmiany.

Na efektywność ekonomiczną analizowanych instytucji wpływ będzie miało również wprowadzenie stabilizującej reguły wydatkowej o charakterze antycyklicznym, które nastąpiło po wprowadzeniu do ustawy o finansach publicznych art. 112aa ${ }^{31}$. Reguła ta ma zapewnić długookresową stabilność finansów na poziomie budżetu państwa i sprzyjać stabilności makroekonomicznej. Głównym założeniem wprowadzenia reguły stabilizującej jest określenie dopuszczalnego wzrostu wydatków sektora publicznego, co w dłuższej perspektywie ma się przyczynić do uzdrowienia finansów publicznych. Wdrożenie reguły oznacza również wypełnienie wymogów unijnych dotyczących utrzymania deficytu sektora instytucji rządowych i samorządowych znacząco poniżej $3 \% \mathrm{PKB}^{32}$.

Wprowadzenie nowej reguły wydatkowej, która może dodatkowo obniżyć dochody jednostek samorządu terytorialnego, np. z tytułu dotacji i subwencji, przy jednoczesnym obowiązywaniu przepisów nakładających na te jednostki ograniczenia w zakresie limitów spłat zadłużenia w poszczególnych latach budżetowych, powoduje określone skutki dla całej gospodarki. Ograniczenie poziomu inwestycji, w tym inwestycji infrastrukturalnych, przez jednostki sektora finansów publicznych oraz wydłużanie okresów spłat kredytów i pożyczek nie spowodują wzrostu dobrobytu społecznego. Konieczność dostosowania bardzo wrażliwych przepisów związanych z deficytem budżetowym do wymogów unijnych nie budzi wątpliwości. Z drugiej strony jednak, konsekwencje wynikające z szybkiej ścieżki legislacyjnej oraz w związku z tym konieczność ciągłych nowelizacji przepisów prawa nie powinny mieć negatywnego wpływu na funkcjonowanie całego sektora finansów publicznych, w tym jednostek samorządu terytorialnego.

Podsumowując, można zatem stwierdzić, że regulacje prawne w obszarze prawa finansowego muszą służyć rozwiązywaniu określonych pro-

31 Ustawa z dnia 8 listopada 2013 r. o zmianie ustawy o finansach publicznych oraz niektórych innych ustaw (Dz.U., poz. 1646.).

32 Traktat o funkcjonowaniu Unii Europejskiej (Dz.Urz. UE C 326, Tom 55, 26 października 2012 r.). 
blemów gospodarczo-społecznych oraz, co istotne, muszą być wykonalne. W przeciwnym razie tracą swoje uzasadnienie i albo są zmieniane bądź usuwane, albo nie są przestrzegane. Efektywność ekonomiczna stanowi zatem ważny aspekt tworzenia prawa.

\section{Bibliografia:}

Boratyński J., Sprawiedliwość społeczna w Konstytucji, „Edukacja Prawnicza” 2009, nr 5, s. 12-13.

Dubisz S. (red.), Uniwersalny słownik języka polskiego PWN, t.1, Warszawa 2003.

Miemiec W., Sawicka K., Miemiec M., Prawo finansów publicznych sektora samorzqdowego, Wolters Kluwer, Warszawa 2013.

Public finances in EMU - 2000, „European Economy” 2000, nr 3.

Report on Public finances in EMU 2012, „European Economy” 2012, nr 4, DOI: http://dx.doi.org/10.2765/18911

Salachna J.M., Granice samodzielności legislacyjnej jednostek samorzq̨du terytorialnego, ODDK, Gdańsk 2012.

Sedlaczek T., Ekonomia to niebezpieczna religia, „Dziennik Gazeta Prawna” 2012, nr 233 (z dn. 30 listopada 2012 r.).

Stelmach J., Brożek B., Metody prawnicze, wyd. 2, Wolters Kluwer, Kraków 2006.

Stelmach J., Brożek B., Załuski W., Dziesięć wykładów o ekonomii prawa, Wolters Kluwer, Warszawa 2007.

Swianiewicz T., Finanse lokalne - teoria i praktyka, Municipium, Warszawa 2004.

Stroiński R.T., Ekonomiczna analiza prawa czyli w oszukiwaniu efektywności, „Kwartalnik Prawa Prywatnego” 2002, nr 3, s. 549-583. 